\title{
Al-Chizan
}

Jurnal Pemikiran Hukum Islam

ISSN 1907-0985, E ISSN 2442-8256

Vol. 15, No. 1, 2019, h. 155-182

DOI: https://doi.org/10.30603/am.v15i1.977

\section{Implementasi Zakat Profesi terhadap Aparatur Sipil Negara di Pemerintah Daerah Kabupaten Bone Bolango}

\section{Faisal Pakaya, Lahaji}

Baznas Kabupaten Bone Bolango, Pascasarjana IAIN Sultan Amai Gorontalo Email: fpakaya@gmail.com; lahaji@iaingorontalo.ac.id

Abstract: This study aims to discuss the implementation of professional zakat in the State Civil Apparatus in Gorontalo District Government. This research is a field research with data collection methods such as observation, interviews, questionnaires and documentation. The data collected is processed and analyzed with descriptive qualitative. The results showed that: First, the Regional Government of Bone Bolango District had carried out the mandate of Law Number 23 of 2011 and Government Regulation Number 14 of 2014; Second, the State Civil Apparatus in the Regional Government of Bone Bolango Regency has a different understanding related to the existence of professional zakat; and Third, the receipt of professional zakat in the Regional Government of Bone Bolango Regency is quite high and this can improve the welfare of the community if it is distributed according to the procedure.

Keywords: Professional Zakat, State Civil Apparatus, Bone Bolango Regency

\section{Implementation of Professional Zakat on State Civil Apparatuses in the Regional Government of Bone Bolango Regency}

Abstrak: Penelitian ini bertujuan membahas implementasi zakat profesi pada Aparatur Sipil Negara di Pemerintah Daerah Kabupaten Gorontalo. Penelitian ini adalah penelitian lapangan dengan metode pengumpulan data berupa pengamatan, wawancara, angket dan dokumentasi. Data yang dikumpulkan diolah dan dianalisis dengan deskriptif kualitatif. Hasil penelitian menunjukkan bahwa: Pertama, Pemerintah Daerah Kabupaten Bone Bolango telah menjalankan amanat dari Undang-Undang Nomor 23 Tahun 2011 dan Peraturan Pemerintah Nomor 14 Tahun 2014; Kedua, Aparatur Sipil Negara di Pemerintah Daerah Kabupaten Bone Bolango memiliki pemahaman yang berbeda terkait adanya zakat profesi; dan Ketiga, penerimaan zakat profesi di Pemerintah Daerah Kabupaten Bone Bolango cukup tinggi dan hal ini dapat meningkatkan kesejahteraan masyarakatnya jika didistribusikan sesuai prosedurnya.

Kata Kunci: Zakat Profesi, Aparatur Sipil Negara, Kabupaten Bone Bolango 
Implementasi Zakat Profesi terhadap Aparatur Sipil Negara di Pemerintah Daerah Kabupaten Bone Bolango

\section{A. Pendahuluan}

Zakat adalah salah satu rukun Islam yang wajib ditunaikan oleh setiap muslim. Zakat memiliki hikmah yang dikategorikan dalam dua dimensi, yaitu dimensi vertikal dan dimensi horizontal. Zakat merupakan perwujudan ibadah seseorang kepada Allah swt. sekaligus sebagai perwujudan dari rasa kepedulian sosial (ibadah sosial). Menunaikan zakat adalah urusan individu sebagai pemenuhan kewajiban seorang muslim, penunaian zakat adalah kewajiban, zakat adalah urusan kepada Allah (vertikal). Apabila seorang muslim telah melaksanakan zakat, berarti telah beribadah dan melaksanakan kewajibannya di sisi Allah dan akan mendapat ganjaran sebagaimana yang Allah telah janjikan. ${ }^{1}$

Zakat sebagai ajaran yang berhubungan dengan persoalan ekonomi, maka persoalan zakat ini menjadi menarik untuk dikaji, sebab institusi zakat pernah terbukti mampu membawa kesejateraan ekonomi bagi masyarakat islam sebagaimana yang pernah dipraktekkan oleh para Khulafaur Rasyidin semisal Khalifah Umar bin Abdul Azis, konon para muzakki sampai tidak menemukan mustahik (penerima) zakat, dikarenakan masyarakat Islam pada saat itu telah terbebas dari kemiskinan. ${ }^{2}$

Keberadaan zakat beserta sistem yang terbangun lewat institusi ini memberikan gambaran bagaimana Islam membangun keadilan ekonomi melalui instrumen praktek zakat terutama terutama di zaman Khulafaur Rasyidin. Namun demikian meski zakat termasuk ibadah namun bukanlah kategori ibadah murni, tetapi termasuk ibadah yang memiliki karakteristik sosial (ibadah maliyah).

Kewajiban zakat di dalam Alquran dijelaskan sebanyak 27 ayat yang mensejajarkan antara kewajiban shalat dalam berbagai bentuk kata. Kesediaan berzakat dipandang sebagai indikator utama ketundukan seseorang hamba terhadap ajaran Islam dan sebagai ciri utama mukmin yang akan mendapatkan rahmat dan pertolongan Allah swt., dan dipandang pula sebagai seseorang yang berkeinginan membersihkan diri dan jiwanya dari berbagai sifat buruk, seperti tamak, rakus, egois, bakhil sekaligus mensucikan dan mengembangkan harta yang dimilikinya.

\footnotetext{
${ }^{1}$ Asnaini, Zakat Produktif dalam Perspektif Hukum Islam (Cet. I; Yogyakarta: Pustaka Pelajar, 2008), 1.

${ }^{2}$ Muhammad, Zakat Profesi: Wacana Pemikiran dalam Fiqih Kontemporer (Jakarta: Salemba Diniyah, 2002), 37.
} 
Perintah pelaksanaan kewajiban berzakat ini dijelaskan melalui firman Allah swt.:

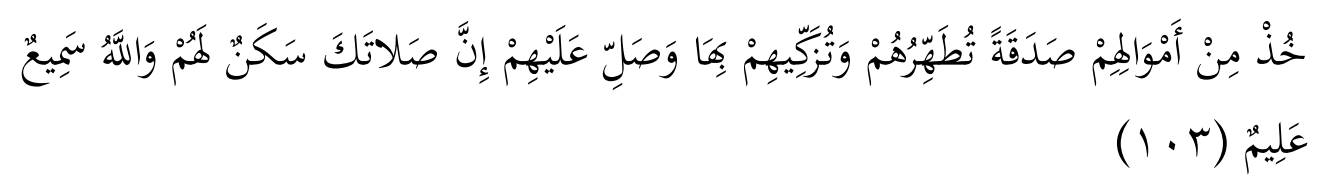

Terjemahnya:

Ambillah zakat dari sebagian harta mereka, dengan zakat itu kamu membersihkan dan mensucikan mereka dan mendoalah untuk mereka. Sesungguhnya doa kamu itu (menjadi) ketenteraman jiwa bagi mereka. dan Allah Maha mendengar lagi Maha mengetahui (QS al-Taubah/9: $103){ }^{3}$

Zakat di dalam Islam dibagi atas dua bagian, yaitu zakat fitrah dan zakat harta (mā). Zakat fitrah dikeluarkan pada bulan Ramadhan, sedangkan zakat māl dikeluarkan apabila sudah cukup senisab dan 1 tahun. Zakat māl dapat berupa emas, harta perniagaan, penghasilan, profesi dan lain sebagainya. Dewasa ini zakat profesi semakin diperkenalkan yang merupakan varian dari zakat māl yang mutakhir. Zakat profesi adalah zakat yang harus dikeluarkan berkaitan dengan hasil usaha seseorang selain zakat pertanian dan peternakan. Untuk mengelola zakat, infaq, sedekah, pemerintah membentuk lembaga non struktural yaitu Badan Amil Zakat Nasional (Baznas) berdasarkan Undang-Undang Nomor 23 Tahun 2011 tentang Pengelolaan Zakat, yang sebelumnya dikenal dengan Badan Amil Zakat (BAZ). Selain mengelola zakat, infaq dan sedekah, Baznas juga dapat mengelola dana CSR, dana hibah maupun dana sosial keagamaan lainnya.

Di era sekarang pemerintah mengharapakan agar semua potensi masyarakat ikut dikerahkan untuk mensejahterakan seluruh rakyat Indonesia, termasuk penggunaan zakat. Oleh karena itu, zakat sudah seharusnya dikumpulkan, dikelola dan didaya gunakan dengan sebaikbaiknya demi kemaslahatan seluruh masyarakat. Zakat merupakan potensi ekonomi yang dapat meningkatkan kesejahteraan umat dan mengurangi angka kemiskinan, akan tetapi potensi ekonomi umat tersebut belum tergarap dan terkelola sebagaimana yang diharapkan.

\footnotetext{
${ }^{3}$ Kementerian Agama RI, Al-Qur'an dan Terjemahnya (Jakarta: PT. Sinergi Pustaka Indonesia, 2012 ), 273.
} 
Implementasi Zakat Profesi terhadap Aparatur Sipil Negara di Pemerintah Daerah Kabupaten Bone Bolango

Pemerintah daerah, baik provinsi maupun kabupaten memiliki kebijakan yang berbeda dalam mengimplementasikan Undang-Undang Nomor 23 Tahun 2011 tentang Pengelolaan Zakat. Ada yang mengimplementasikan baik dalam bentuk Peraturan Daerah (Perda), Peraturan Gubernur (Pergub) maupun Peraturan Bupati (Perbup). Namun dalam sebuah pemerintahan daerah keberadaan Perda maupun Perbup tidak menjamin optimalnya pengumpulan zakat di daerah tersebut.

Kabupaten Bone Bolango adalah salah satu kabupaten di Provinsi Gorontalo yang segera menyambut hadirnya Undang-Undang Nomor 23 Tahun 2011 tentang Pengelolaan Zakat. yaitu dengan terbitnya Peraturan Daerah Nomor 11 Tahun 2012 tentang Pengelolaan Zakat. Perda ini diharapkan dapat meningkatkan pengumpulan zakat, khususnya zakat profesi dari Aparatur Sipil Negara (ASN) di Kabupaten Bone Bolango. Paling tidak dengan adanya Perda ini, pihak Baznas Kabupaten Bone Bolango maupun pemerintah daerah mempunyai payung hukum dalam menginstruksikan seluruh ASN muslim di Kabupaten Bone Bolango untuk pengumpulan zakat.

Kenyataan di lapangan sejak dibentuk Baznas Kabupaten Bone Bolango selalu dalam urutan paling bawah pengumpulan zakat jika dibandingkan lima kabupaten/kota lainnya di Provinsi Gorontalo. Baznas Kabupaten lain sudah mencapai pengumpulan 700 juta hingga milyaran rupiah per tahun, sedangkan pengumpulan zakat profesi Baznas Kabupaten Bone Bolango masih di bawah 100 juta per tahun, khususnya dalam 4 tahun terakhir. Menurut data Baznas Kabupaten Bone Bolango pada tahun 2014 pengumpulan zakat profesi sebanyak Rp. 71.727.512,- pada tahun 2015 sebanyak Rp. 63.722.332,- pada tahun 2016 sebesar Rp. 67.142.520,- tahun 2017 sebesar Rp. 82.236.141,--

Awal tahun 2018 sebagai usaha dalam menumbuhkan kesadaran berzakat di kalangan ASN, Pemda Kabupaten Bone Bolango menyelenggarakan kegiatan berupa gerakan zakat infaq sedekah yang meraih rekor MURI dengan tema " 5 menit, 5000 aparat, 500 juta." Kegiatan yang dirangkaikan dengan semangat hari patriotik 23 Januari 2018 tersebut dapat mengumpulkan zakat sebesar Rp. 633.999.400,- Kegiatan ini berdampak positif terhadap pengumpulan zakat dan tingkat kepatuhan ASN dalam membayar zakat profesi. 


\section{B. Fungsi Zakat dalam Kehidupan Sosial Kemasyarakatan}

Islam adalah agama yang rahmatan lil'âlamin yang mengajarkan kepada umatnya untuk mewujudkan kehidupan yang adil, makmur, sejahtera, dan harmonis antara si kaya dan si miskin, kapan dan di manapun berada. Salah satu upaya Islam untuk mewujudkan kesejahteraan umat adalah mewajibkan membayar zakat bagi orang yang telah memenuhi persyaratan. ${ }^{4}$ Dalam konteks inilah, zakat memiliki fungsi yang sangat penting dan strategis sebagai instrumen pemerataan ekonomi yang berkeadilan dan peningkatan kesejahteraan masyarakat miskin. ${ }^{5} \mathrm{Al}-\mathrm{Q}$ ardawî mengemukakan bahwa Allah swt. menyebutkan fakir-miskin pada QS alTaubah/9: 60, pada urutan pertama dan kedua, menunjukkan bahwa fungsi utama zakat adalah untuk meningkatkan kesejahteraan masyarakat miskin bahkan menanggulangi kemiskinan. Menurutnya hal ini merupakan target zakat yang utama dan terpenting. ${ }^{6}$ Berdasarkan hal ini tampak bahwa sesungguhnya zakat merupakan instrumen peningkatan kesejahteraan masyarakat miskin yang efektif, ramah pasar dan bersifat kontinyu.

Lebih lanjut disebutkan oleh Syafi'ie El-Bantanie bahwa kedudukan dan fungsi zakat, antara lain: Pertama, penggunaan dana zakat sudah ditentukan secara jelas dalam syariat (QS al-Taubah/9: 60), yaitu zakat hanya diperuntukkan bagi delapan golongan (ashnaf), orang-orang fakir, miskin, amil zakat,muallaf, memerdekakan budak, orang-orang yang berutang, fi sabilillah, dan ibnu sabil. Jumhur fuqaha sepakat bahwa selain delapan golongan di atas, tidak boleh menerima zakat. Tidak ada satu pihak pun yang berhak mengganti atau mengubah ketentuan ini. Karakteristik ini membuat zakat secara inheren bersifat pro-poor. Zakat akan lebih efektif meningkatkan kesejahteraan masyarakat miskin karena alokasi dana yang sudah pasti dan diyakini akan lebih tepat sasaran (self-targeted); Kedua, zakat memiliki tarif yang rendah dan tetap serta tidak pernah berubah-ubah karena sudah diatur dalam syariat. Misalnya, zakat perdagangan dalam arti yang luas, tarifnya hanya $2.5 \%$. Ketentuan tarif zakat ini tidak boleh diganti atau diubah oleh siapa pun. Oleh karena itu, penerapan zakat tidak akan menganggu insentif investasi dan akan menciptakan transparansi kebijakan

${ }^{4}$ Syafi'ie El-Bantanie, Zakat Infaq dan Sedeqah (Bandung: Salamadani Pustaka Semesta, 2009), 9.

${ }^{5}$ Yusuf al-Qardhawi, Kiat Islam Mengentaskan Kemiskinan (Jakarta: Gema Insani Press, 1995), 88.

${ }^{6}$ Y usuf al-Qardhawi, Kiat Islam Mengentaskan Kemiskinan, 63. 
Implementasi Zakat Profesi terhadap Aparatur Sipil Negara di Pemerintah Daerah Kabupaten Bone Bolango

publik serta memberikan kepastian usaha; Ketiga, zakat memiliki tarif berbeda untuk jenis harta yang berbeda, dan memberikan keringanan bagi usaha yang memiliki tingkat kesulitan produksi lebih tinggi. Misalnya, zakat untuk produk pertanian yang dihasilkan dari lahan irigasi tarifnya adalah $5 \%$. Sementara itu, jika dihasilkan dari lahan tadah hujan tarifnya $10 \%$. Karakteristik ini membuat zakat bersifat market friendly, sehingga tidak akan menganggu iklim usaha; Keempat, zakat dikenakan pada basis yang luas dan meliputi berbagai aktivitas perekonomian. Zakat dipungut dari produk pertanian, hewan peliharaan, simpanan emas dan perak, aktivitas perniagaan komersial, dan barang-barang tambang yang diambil dari perut bumi. Pendapatan yang dihasilkan dari aset atau keahlian pekerja. Artinya, potensi zakat itu sangat besar. Hal ini menjadi modal dasar yang penting bagi pembiayaan program-program peningkatan kesejahteraan masyarakat miskin; Kelima, zakat adalah "pajak spiritual" yang wajib dibayar oleh setiap Muslim yang terkena kewajiban berzakat dalam kondisi apapun. Oleh karena itu, penerimaan zakat cenderung stabil dan berkesinambungan. Hal ini akan menjamin keberlangsungan program-program penigkatan kesejahteraan masyarakat miskin dalam jangka waktu yang cukup panjang. ${ }^{7}$

Pemungutann dan penggunaan zanat bertujuan untuk merealisasikan fungsi-fungsi sosial, ekonomi, dan permodalan kehidupan yang adil dalam masyarakat Islam, selain tentunya bertujuan ibadah sebagaimana penjelasan berikut ini:

\section{Fungsi Sosial}

Secara umum, fungsi sosial dari zakat adalah memelihara menyelamatkan modal manusiawi, dengan cara memotong bagian tertentu dari keuntungan modal ekonomi, yang kemudian diarahkan kepada bidangbidang yang wajib dibiayai, sehingga keselamatan modal manusiawi maupun modal ekonomi bisa terjamin, dan terjamin pula pertumbuhan sosial dari manusia itu sendiri dan pertumbuhan masyarakat Islam. Selain tujuan pertumbuhan internal masyarakat Islam, zakat juga bertujuan mempertahankan negara terhadap musuh dan ancaman dari luar, dan juga untuk tujuan perjuangan di jalan Allah, dakwah Islam dan pembelaannya. Zakat dapat berfungsi sosial sebagai berikut:

\footnotetext{
${ }^{7}$ Syafi'ie El-Bantanie, Zakat Infaq dan Sedeqah, 9-11.
} 
a. Sarana jaminan sosial dan sarana pemersatu masyarakat

Zakat berfungsi sebagai sarana jaminan dan pemersatu masyarakat dalam memenuhi kebutuhan-kebutuhan pokok tiap-tiap individu, memberantas kemiskinan dan pembiaran terhadap sesama kaum muslimin. Jumhur fuqaha sepakat bahwa selain delapan golongan di atas, tidak boleh menerima zakat. ${ }^{8}$ Tidak ada satupun yang berhak mengganti atau mengubah ketentuan ini. Kemudian, apabila hasil pemungutan itu tidak cukup, kalau pemerintah adil, boleh saja memungut secara teratur sebagian harta orangorang kaya secukupnya untuk menutupi kebutuhan-kebutuhan pokok individu maupun masyarakat miskin. Dengan kata lain, pemerintah boleh memungut pajak disamping zakat, untuk menunjang tugas soaial. Apabila kebutuhan-kebutahan yang pokok telah merosot sampai ke batas darurat, menghilangkan keadaan darurat hukumnya adalah fardhu kifâyah, ${ }^{9}$ selain kewajiban membayar zakat itu sendiri. Hal ini karena pembiaran sesama muslim, menurut fuqaha tidak diperkenankan.

Adapun kebutuhan-kebutuhan sosial dari setiap orang pada zaman sekarang, antara lain: (1) kebutuhan-kebutuhan hidup yang pokok; makan, minum, dan seks; (2) keamanan dan perlindungan; rumah dan pakaian; (3) kesejahteraan soaial, kesehatan, pengajaran, perhubungan, latihan dan pendidikan sosial dan berbagai pengembangan sosial lainnya, yang dapat meningkatkan kemampuan seseorang untuk memberi dan melakukan pekerjaannya; dan (4) kebudayaan, olah raga dan hiburan. ${ }^{10}$

b. Sebagai pelunak hati dan alat penyebaran Islam

Bukankah zakat itu di antaranya digunakan untuk para muallaf yang dibujuk hatinya, orang-orang yang patut diberi zakat sebagai pelunak hati mereka atau hati kaumnya, atau untuk memperteguh keislaman dalam hatinya. Orang-orang yang dibujuk hatinya itu ada empat golongan, yaitu: (1) sebagian adalah mereka yang dibujuk hatinya agar membantu kaum muslimin; (2) sebagian lagi dibujuk hatinya agar tidak menyerang kaum muslaimin; (3) sebagian lagi dibujuk hatinya agar masuk Islam; dan (4) sebagian lagi dibujuk agar kaumnya atau keluarganya masuk Islam. ${ }^{11}$

\footnotetext{
${ }^{8}$ Sayyid Sabiq, Fiqh Sunnah, Jilid 1 (Jakarta: Pena Publishing, 2002), 86.

${ }^{9}$ Abdul Wahhab Khallaf, Ilm Usul Fiqh, terj. Moh. Zuhri, Ilmu Ushul Fiqh (Semarang: Toha Putra Group, 1994), 310.

${ }^{10}$ Syauqi Ismail Sahhatih, Al-Bunuk al-Islâmiyah (Saudi Arabia: Dâr al-Syurứq, 1397 H.), 79.

${ }^{11}$ Syauqi Ismail Sahhatih, Al-Bunuk al-Islâmiyah, 80.
} 
Implementasi Zakat Profesi terhadap Aparatur Sipil Negara di Pemerintah Daerah Kabupaten Bone Bolango

Jadi boleh saja masing-masing dari empat golongan tersebut diberi zakat, yaitu bagian yang ditujukan untuk para mu'allaf, baik mereka sudah Islam atau masih musyrik. Pemberian kepada para muallaf bertujuan pembelaan dan dakwah Islam. Kalau zakat itu diberikan kepada para pahlawan dan pejuang dengan tujuan pembelaan dakwah, demikian pula tujuan diberikannya zakat kepada mereka yang dibujuk hatinya.

c. Untuk memerdekakan budak dan membebaskan sesama manusia dari perbudakan dan perhambaan, serta mengembalikan pada kemuliaannya dan kemerdekaannya sebagai anak Adam.

Al-Qur'an memang telah menetapkan antara penggunaan zakat itu, ada sebagian yang digunakan untuk memerdekakan budak. Hal ini cukup menjadi bukti bahwa negara Islamlah yang pertama kali diseluruh dunia yang memerangi perbudakan dan menetapkan di antara zakat sebagian untuk memerdekakan budak, membebaskan hamba sahaya dan mengembalikan umat manusia kepada kemerdekaan dan kemuliaannya sebagai anak Adam. Bagian zakat yang ditujukan untuk memerdekakan budak, bisa digunakan dengan tiga cara, yaitu:

1. Harta zakat digunakan untuk membeli budak laki-laki maupun perempuan, kemudian dimerdekakan oleh pemerintah.

2. Diberikan kepada hamba mukatab, yaitu hamba yang telah sepakat dengan tuannya untuk memperoleh kemerdekaan, asalkan dia sanggup menyerahkan kepada tuannya untuk memperoleh kemerdekaan,asalkan dia sanggup menyerahkan kepada tuannya itu sejumlah harta. Pemberian zakat kepada hamba mukatab adalah untuk menolongnya memenuhi sejumlah harta yang harus dibayar tersebut, agar ia segera memperoleh kemerdekaan.

3. Untuk menebus orang-orang Islam yang ditawan musuh, jangan sampai dijadikan budak. Bahkan, menurut Imam Malik, umat Islam berkewajiban menebus saudara-saudara mereka yang tertawan, sekalipun untuk itu, mereka terpaksa menguras habis seluruh harta mereka. ${ }^{12}$

Setelah tidak ada lagi perbudakan pada zaman sekarang, jika mau meneruskan realisasi dari fungsi sosial zakat, maka sebagian dari zakat didistribusikan untuk memerdekakan bangsa-bangsa terjajah, yang sebenarnya justru merupakan jenis perbudakan terburuk pada zaman

\footnotetext{
${ }^{12}$ Syauqi Ismail Sahhatih, Al-Bunuk al-Islâmiyah, 81.
} 
sekarang, dan termasuk juga di antaranya untuk melepaskan minoritas Islam dari penindasan, tekanan, dan keterbelakangan.

d. Dengan adanya bagian untuk orang-orang yang berutang (gharimin)

Zakat merupakan suatu sarana untuk memperbesar volume harta yang disediakan untuk memberi jaminan sosial dalam soal utang-piutang, dan merupakan payung sosial yang melindungi kaum miskin bersama keluarga mereka manakala mereka mempunyai utang. Karena gudang penyimpanan zakat boleh saja melunasi utang-utang yang adil, yang bertumpuk dari para debitur, yang tidak sanggup lagi melunasinya, baik merupakan pemberian yang takkan diminta kembali oleh baitul mal, ataupun merupakan pembelanjaan dalam bentuk utang yang baik (al-qardhul hasan), yang nantinya harus dikembalikan lagi oleh debitur itu kepada baitul mal, apabila ia telah terlepas dari kesulitannya. Dengan demikian, gudang penyimpanan zakat penting sekali perannya dalam memperbesar volume harta yang disediakan sebagai jaminan sosial dalam soal utang-piutang, dan juga mendorong orang untuk mempercayai orang lain, di samping membukakan pintu bagi kaum miskin yang mempunya utang, pada saat segala pintu tertutup rapat baginya. ${ }^{13}$

2. Fungsi Ekonomi

Sistem-sistem perpajakan erat hubunganya dengan sistem-sistem perekonomian. Demikian pula pungutan (zakat) ternyata mempunyai peranan aktif dalam perekonomian. Zakat merupakan pungutan yang mendorong kehidupan ekonomi hingga tercipta padanya dinamika perputaran roda ekonomi.

Islam mengharamkan riba dan setiap pinjaman yang menarik keuntungan adalah riba. Akan tetapi, Islam mengahalalkan jual beli dan laba perniagaan dengan cara berjual-beli, baik dengan harga yang dibayar tunai ataupun harga yang ditangguhkan pembayaranya, yang berbeda dari harga tunai. $^{14}$

Islam memandang riba merupakan keuntungan yang menjijikan dan laba yang haram dari modal berupa uang.Dalam sistem perkonomian Islam, uang itu takkan mempunyai keuntungan yang baik dan laba yang halal,

\footnotetext{
${ }^{13}$ Syauqi Ismail Sahhatih, Al-Bunuk al-Islâmiyah, 82.

${ }^{14}$ Shalah al-Shawi dan Abdullah al-Mushlih, Fiqh Ekonomi Keuangan Islam, (Jakarta: Dârul Haq, 2008), h. 87.
} 
Implementasi Zakat Profesi terhadap Aparatur Sipil Negara di Pemerintah Daerah Kabupaten Bone Bolango

kecuali bila berjalin dan bergabung dengan salah satu atau lebih faktorfaktor produksi dibidang investasi dan penanaman modal di berbagai sektor. ${ }^{15}$ Ekonomi Islam tidaklah berdasarakan riba, atau berdasarkan sistem permodalan dengan keuntungan tetap dan tertentu, yang dijamin sebelumnya dalam kaitannya dengan modal. Akan tetapi, ekonomi Islam itu berdasarkan sistem kerja sama dan koperasi, dengan pembagian laba, yakni pembagian hasil karya dan usaha yang merata dan diketahui, dengan berlandaskan prinsip, laba berhadapan dengan rugi, keuntungan berhadapan dengan tekor,dan mengambil berhadapan dengan memberi. ${ }^{16}$

Oleh karena itu, pada saat yang sama, ekonomi Islam harus berlandaskan pada pengarahan zakat agar memberi dorongan terhadap kehidupan ekonomi, sebagai suatu sistem penarikaniuran, dengan tujuan mengarahkan dan mengfungsikan uang supaya di investasikan dan dikembangkan, hingga ia tidak termakan oleh peraturan zakat. Dengan demikian mencairlah uang itu memodali perusahaan-perusahaan lewat pertumbuhan ekonomi. Semakin tinggi grafik pertumbuhan-pertumbuhan ekonomi, semakin turun pula ukuran pungutan zakat. Hal ini akan memberi dorongan kepada mereka pemilik modal untuk berusaha meningkatkan produksi mereka danmemperbaiki mutunya sebaik-baiknya, sehingga pada gilirannya akan terwujud pertumbuhan ekonomi yang pesat.

Pembagian zakat juga memainkan peranan ekonomi yang penting dalam mendorong peredaran uang dan memperluas arus uang. Karena dengan adanya zakat, semakin kuatlah daya beli. Dengan demikian, terjadilah pembelanjaan konsumtif untuk memperoleh barang ataupun jasa. Zakat juga aktif dalam merealisasikan keseimbangan yang stabil antara arus barang dan arus uang. Kedua-duanya berjalan dari arah yang berlawanan, yang satu menyempurnakan yang lain. Akan tetapi, dengan adanya pembagian zakat secara luas, ia meningkatkan pembelanjaan umum untuk dikonsumsikan pada barang dan jasa. Karena orang-orang fakir dan miskin yang tidak berpenghasilan sama sekali atau yang paspasan saja, mendapat bantuan pendapatan berupa uang, yang kemudian mereka gunakan untuk memenuhi konsumsi keluarganya danmembeli barang dan jasa yang mereka butuhkan, atau mereka mendapat bantuan berupa benda, yakni barang dan jasa yang langsung diberikan kepada mereka.

\footnotetext{
${ }^{15}$ Shalah al-Shawi dan Abdullah al-Mushlih, Fiqh Ekonomi Keuangan Islam, 447.

${ }^{16}$ Andiwarman A. Karim, Bank Islam Analisis Fiqh dan Keuangan (Jakarta: Raja Grafindo Persada, 2006), 52.
} 
Demikianlah, dan akhirnya bahwa pembagian untuk para gharim yaitu mereka yang menanggung utang bertumpuk-tumpuk hingga tak sanggup lagi melunasinya, di lapangan kegiatan ekonomi, akan menyebabkan meningkatnya volume harta yang disediakan untuk memberi pinjaman-pinjaman yang baik (tanpa bunga) sehingga pinjam-meminjam dibidang produksi, perdagangan dan pemberian lisensi dagang mendapat dorongan. ${ }^{17}$ Dengan demikian, gudang penyimpanan yang baik (al-qurdh alhasan) itu akan memainkan suatu peran ekonomi yang penting dan nyata dalam kegiatan perekonomian dan perdagangan dan dalam memperbesar volume harta yang tersedia untuk dipinjam berupa utang-utang produktif dan utan-utang perniagaan. ${ }^{18}$

\section{Fungsi Zakat dalam Peredaran Uang}

Wajarlah bila hubungan antara penyediaan uang dan barang-barang simpanan dengan kebutuhan serta kelebihan uang dalam ekonomi Islam yang tidak terdapat harta bunga, berbeda secara radikal dari hubungan antara penyediaan uang dan barang-barang simpanan dengan kebutuhan uang dalam kerangka harta bunga. Hal ini karena aliran-aliran ekonomi pun sebenarnya mengalami perkembangan dan perubahan dalam penilaiannya mengenai harta bunga dan fungsinya sebagai harta penangguhan menjadi harta pengorbanan atas diedarkannya uang. Jadi, bukan merupakan harta penangguhan lagi. Begitu juga, bunga itu sendiri tidak lagi merupakan imbalan atas penyimpanan, tetapi imbalan atas ketidakterpeliharaanya uang disaat dalam kondisi beredar penuh.

Dengan dihilangkannya sistem harta bunga seperti halnya pada sistem ekonomi Islam, yang sekaligus diwajibkan pula membayar zakat uang, zakat uang itu mendesak kehidupan ekonomi untuk melakukan peredaran uang, serta mendorong aktivitas permodalan dalam negeri pada proyek-proyek perekonomian dan perdagangan. Dengan demikian, hubungan yang mengatur supply dan demand uang akan terikat dengan konsep-konsep dan prinsip-prinsip Islam sebagai berikut:

a. Uang harus selalu digabungkan dengan satu atau lebih factor-faktor produksi, supaya berkembang sedangkan keuntungan investasi tetap terikat dengan prinsip untung-rugi, laba-rugi dan mengambil-menerima.

\footnotetext{
${ }^{17}$ Syafi' ie El-Bantanie, Zakat Infaq dan Sedeqah, 11-12.

${ }^{18}$ Syauqi Ismail Sahhatih, Al-Bunuk al-Islâmiyah, 83-86.
} 
Implementasi Zakat Profesi terhadap Aparatur Sipil Negara di Pemerintah Daerah Kabupaten Bone Bolango

b. Endapan-endapan uang apabila telah mencapai nisap dan berulang tahun, harus tunduk pada peraturan zakat uang, seharga 2,5 persen pertahun, karena dihukumi sama dengan harta yang punya potensi berkembang sendiri, sekalipun dalam kenyataanya tidak berkembang. ${ }^{19}$

Struktur penitipan pada bank-bank Islam tidaklah sama dengan struktur penitipan pada bank-bank dagang yang memakai kerangka harga bunga ribawi. Hal ini karena titipan-titipan investasi secara koperetif menduduki tempat pertama. Pada titipan di bank-bank Islam. Kemudian, karena titipan-titipan investasi, baik yang berupa titipan tetap amaupun titipan beresiko (sementara), merupakan salah satu faktor kewajiban nonmoneter, lain halnya dengan titipan-titipan berjalan (rekening berjalan) yang menciptakan salah satu faktor penting di antara faktor-faktor kewajiban moneter, semakin bertambahnya saldo kewajiban-kewajiban nonmoneter dibank-bank Islam, akhirnya akan mengakibatkan semakin berkurangnya beberapa kewajiban moneter. ${ }^{20}$

\section{Implementasi dan Potensi Zakat Profesi di Kabupaten Bone Bolango}

Implementasi zakat profesi di Kabupaten Bone Bolango merupakan refleksi keagamaan kementerian agama yang ditindaklanjuti oleh pemerintah dengan terbitnya Peraturan Daerah Nomor 11 Tahun 2012 dan keterlibatan ulama ( $q a d h i)$ khususnya para da'i meskipun belum ada sebuah wadah yang bisa menaungi para ulama atau dikenal dengan Majelis Ulama Indonesia (MUI). Pada awal terbentuknya Kabupaten Bone Bolango, Kementerian Agama Kabupaten sangat berperan dalam mempelopori pengumpulan zakat, infaq dan sedekah. Implementasi zakat profesi yang dipelopori oleh Kementerian Agama, pemerintah dan ulama tersebut merupakan tindakan yang didasari oleh paham kewajiban zakat.

Badan Amil Zakat (BAZ) Kabupaten Bone Bolango untuk pertama kali dibentuk berdasarkan Keputusan Bupati Bone Bolango Nomor 112 Tahun 2003, seiring dengan terbentuknya Kabupaten Bone Bolango sebagai kabupaten yang baru dimekarkan berdasarkan Undang-Undang Nomor 6 Tahun 2003, Kabupaten Bone Bolango adalah kabupaten keempat di Provinsi Gorontalo yang merupakan pemekaran dari Kabupaten Gorontalo.

\footnotetext{
${ }^{19}$ Syauqi Ismail Sahhatih, Al-Bunuk al-Islâmiyah, 87.

${ }^{20}$ Syauqi Ismail Sahhatih, Al-Bunuk al-Islâmiyah, 89-92.
} 
Berdasarkan Keputusan Menteri Agama Nomor 373 Tahun 2003 bahwa kepengurusan Badan Amil Zakat berlaku selama 3 tahun, terdiri atas dewan pertimbangan, komisi/pengawas, dan badan pelaksana. Dalam menjalankan program masih senantiasa bermitra dengan kementerian agama, disamping karena letak kantor di lingkungan Kementerian Agama, juga mayoritas pengurus adalah pegawai Kementerian Agama.

Setelah terbitnya Undang-Undang Nomor 23 Tahun 2011 tentang Pengelolaan Zakat, maka kepengurusan Badan Amil Zakat Kabupaten Bone Bolango berlaku untuk 5 tahun dan tidak boleh lagi ASN masuk dalam kepengurusan. Sejak pertama kali dibentuk tahun 2003 hingga terbentuk pengurus transisi tahun 2017 tercatat bahwa Baznas Kabupaten Bone Bolango telah mengalami pergantian pengurus sebanyak 4 kali atau 4 periode kepengurusan dengan dua kali pergantian Ketua, yaitu H. Abd. Raif Huntoyungo, S.Ag. dan Imran Ahmad, SE, MM., masing masing 2 periode. Kemudian dibentuk pengurus transisi berdasarkan Keputusan Bupati Bone Bolango Nomor 90.a/KEP/BUP.BB/135/2017 tentang Pengangkatan Pimpinan Badan Amil Zakat Nasional Kabupaten Bone Bolango Periode 2017-2022 sebagai tindak lanjut dalam menjalankan aturan Undang-Undang Nomor 23 Tahun 2011 tentang Pengelolaan Zakat.

Sebagai wilayah yang memiliki potensi dalam pengumpulan, pengelolaan dan pendayagunaan zakat profesi, posisi Kabupaten Bone Bolango menjadi sangat penting. Artinya implementasi zakat profesi bagi ASN memiliki corak tersendiri yang khas dan unik. Keunikan tersebut terletak pada relasi paham tentang kewajiban zakat, terbitnya Perda, Perbup dan adanya beberapa surat edaran dan himbauan dari Bupati, namun pengumpulan zakat di Kabupaten Bone Bolango masih tergolong rendah, Disamping itu, tidak adanya lembaga keagamaan khususnya MUI yang juga menjadi faktor penentu dalam membangun kesadaran para ASN untuk membayar zakat profesi.

Berdasarkan data dari Badan Kepagawaian Daerah (BKD) dan Dinas Pendapatan, Pengelolaan Keuangan dan Aset Daerah (DPPKAD) bahwa jumlah ASN di Kabupaten Bone Bolango adalah 3730 orang. Dengan perincian menurut golongan, yaitu: Golongan IV sebanyak 811 orang, Golongan III sebanyak 2049 orang, Golongan II sebanyak 862 orang dan Golongan I sebanyak 8 orang. Jika dilihat potensi zakat profesi dari seluruh ASN tersebut sebesar Rp. 367.242.588,- 
Implementasi Zakat Profesi terhadap Aparatur Sipil Negara di Pemerintah Daerah Kabupaten Bone Bolango

Tabel 1

Jumlah ASN dan Potensi Zakat

\begin{tabular}{|c|c|c|c|c|r|r|}
\hline No & Gol & $\begin{array}{c}\text { Jumlah } \\
\text { Pegawai }\end{array}$ & $\begin{array}{c}\text { Gaji Per } \\
\text { Individu }\end{array}$ & $\begin{array}{c}\text { Gaji } \\
\text { Keseluruhan }\end{array}$ & $\begin{array}{c}\text { Potensi } \\
\text { Zakat Per } \\
\text { Individu }\end{array}$ & $\begin{array}{c}\text { Potensi Zakat } \\
\text { Keseluruhan }\end{array}$ \\
\hline 1 & IV & 811 & $5,236,922.00$ & $4,247,200,800.00$ & $130,924.00$ & $106,179,364.00$ \\
\hline 2 & III & 2049 & $3,827,040.00$ & $7,841,621,900.00$ & $95,676.00$ & $196,040,124.00$ \\
\hline 3 & II & 862 & $2,993,707.00$ & $2,580,576,200.00$ & $74,842.00$ & $64,514,385.00$ \\
\hline 4 & I & 8 & $2,543,575.00$ & $20,348,600.00$ & $63,589.00$ & $508,715.00$ \\
\hline \multicolumn{2}{|c|}{ Total } & & & & & $367,242,588.00$ \\
\hline
\end{tabular}

Sumber: Data Dinas Badan Keuangan dan Pendapatan Daerah Kabupaten Bone Bolango

Data di atas adalah berdasarkan gaji bersih sebagaimana wawancara dengan Anas Paudi, Sekretaris Dinas Badan Keuangan dan Pendapatan Daerah. ${ }^{21}$ Juga disampaikan Ir. H. Ishak Ntoma mengatakan zakat profesi dipotong dari gaji atau penghasilan, penghasilan tidak tetap kalau gaji ada tunjangan TKD/TPP. Gaji 3 juta, TKD 1 juta berarti penghasilan 4 juta. Penghasilan diakumulasi untuk menetapkan kewajiban mengeluarkan zakat profesi. ${ }^{22}$

Menurut data dari Baznas Kabupaten Bone Bolangobahwa pengumpulan 4 tahun terakhir, yaitu tahun 2015, 2016, dan 2017 mengalami pluktuasi setiap tahunnya. Pada tahun 2014 pengumpulan zakat profesi sebesar Rp. 71.727.512,- pada tahun 2015 sebesar Rp .63.722.332 ,- pada tahun 2016 sebesar Rp. 67.142.520,- tahun 2017 sebesar Rp. 82.236.141,Kami mengakui bahwa zakat di Kabupaten Bone Bolango termasuk yang paling rendah di Provinsi Gorontalo jika dibandingkan dengan kabupaten/kota lainnya. Alhamdulillah, awal kepengurusan kami, yaitu bulan 17 Ramadhan 1438 H/ Juni 2017 M, diawali dengan Launching Zakat, khususnya zakat fitrah oleh Bupati Bone Bolango H. Hamim Pou, S.Kom, $\mathrm{MH}$, yang langsung diikuti oleh para Kepala OPD dan staf lainnya. Zakat yang terkumpul dalam kegiatan itu sebesar Rp. 61.465.300. ${ }^{23}$

${ }^{21}$ Anas Paudi, Sekretaris Dinas Badan Keuangan dan Pendapatan Daerah Kabupaten Bone Bolango, Wawancara, di Kantor Dinas Badan Keuangan dan Pendapatan Daerah Kabupaten Bone Bolango, tanggal 28 Maret 2019.

${ }^{22}$ Ir. H. Ishak Ntoma, Sekretatis Daerah Kabupaten Bone Bolango, Wawancara, di Bone Bolango, tanggal 24 Maret 2019.

${ }^{23}$ H. Harun S. Badjoda, S.IP., Ketua Baznas Kabupaten Bone Bolango, Wawancara, di Bone Bolango, tanggal 26 Februari 2019. 
Tabel 2

Penerimaan Zakat dan Infaq Tahun 2017

\begin{tabular}{|c|c|c|}
\hline No & Uraian & Jumlah Pemasukan \\
\hline 1 & Launching dan Pengumpulan Zakat Fitrah & $61,465,300.00$ \\
\hline 2 & Saldo Kepengurusan Sebelumnya & $27,099,380.00$ \\
\hline 3 & Cabang Dinas Bulango Timur & $523,000.00$ \\
\hline 4 & Kantor Camat Kabila Bone & $1,400,000.00$ \\
\hline 5 & Zakat Mal dari Taufik Sidiki & $300,000.00$ \\
\hline 5 & Zakat Infak & $676,000.00$ \\
\hline 7 & Dikbud Bone Bolango & $2,227,500.00$ \\
\hline 8 & Cabang Dinas Suwawa Tengah & $895,000.00$ \\
\hline 9 & Cabang Dinas Suwawa Timur & $1,825,000.00$ \\
\hline 10 & Sekretariat Daerah Bone Bolango & $2,386,125.00$ \\
\hline 11 & Bulan Mei (tanpa nama) & $1,250,000.00$ \\
\hline 12 & Bagian Hukum & $360,000.00$ \\
\hline 13 & Setoran Baznas & $2,500,000.00$ \\
\hline 14 & Bagian Kesra & $200,000.00$ \\
\hline 15 & Dikbud Bone Bolango (Juni) & $2,197,500.00$ \\
\hline 16 & Dikbud Bone Bolango (Juli) & $2,160,000.00$ \\
\hline 17 & Dikbud Bone Bolango(Agustus) & $2,275,000.00$ \\
\hline 18 & Dikbud Bone Bolango (September) & $2,292,500.00$ \\
\hline 19 & Bagian Tapem & $375,000.00$ \\
\hline 20 & Bappeda & $9,750,000.00$ \\
\hline 21 & Kantor Camat Suwawa Selatan & $420,000.00$ \\
\hline 22 & Kantor Camat Bulango Ulu & $705,000.00$ \\
\hline 23 & UPTD Suwawa Tengah & $447,500.00$ \\
\hline 24 & Bagian Tapem & $394,000.00$ \\
\hline 25 & Bagian Hukum & $360,000.00$ \\
\hline 26 & SMPN 1 Kabila & $5,255,000.00$ \\
\hline 27 & Cabang Dinas Tilong Kabila & $1,215,000.00$ \\
\hline 28 & Dikbud Bone Bolango & $389,318.00$ \\
\hline 29 & Dikbud Bone Bolango & $389,318.00$ \\
\hline 30 & Dikbud Bone Bolango & $2,432,500.00$ \\
\hline 31 & Dikbud Bone Bolango & $2,417,500.00$ \\
\hline \multirow[t]{2}{*}{32} & Sekretariat Daerah Bone Bolango & $7,119,000.00$ \\
\hline & Jumlah & $82,236,141.00$ \\
\hline
\end{tabular}

Sumber: Data Baznas Kabupaten Bone Bolango Tahun 2017

Pada awal tahun 2018 tepatnya tanggal 23 Januari seiring dengan semangat Hari Patriotik 23 Januari, Pemerintah Kabupaten Bone Bolango menyelenggarakan kegiatan gerakan, infaq sedekah bagi ASN sebagai upaya jihad melawan kemiskinan dengan zakat infaq sedekah, dan usaha untuk mensosialisasikan dan menumbuhkah kesadaran dalam mengeluarkan zakat. 
Implementasi Zakat Profesi terhadap Aparatur Sipil Negara di Pemerintah Daerah Kabupaten Bone Bolango

dengan tema "5 menit 5000 ASN 500 juta."24 Gerakan ini merupakan pertama kali ini Indonesia sehingga dicatat dalam Rekor Muri Indonesia. Kegiatan ini selain dikhususkan untuk ASN di lingkungan Pemerintah Daerah Kabupaten Bone Bolango, juga menghimbau instansi vertikal termasuk TNI/Polri. Dari target yang ditentukan 500 juta, even ini justeru melebihi target yaitu dapat menghimpun zakat, infaq, sedekah sebesar Rp.637,999,400.00. Sebagaimana dapat dilhat dari tabel berikut:

Tabel 3

Hasil Pengumpulan Gerakan Zakat, Infaq, Sedekah bagi ASN

\begin{tabular}{|c|l|c|c|}
\hline No & \multicolumn{1}{|c|}{ Uraian } & $\begin{array}{c}\text { Perkiraan } \\
\text { Munfiq }\end{array}$ & Jumlah Penerimaan \\
\hline 1 & Bupati & 1 & $25,000,000.00$ \\
\hline 2 & Wabup & 1 & $5,000,000.00$ \\
\hline 3 & Setda & 1 & $1,500,000.00$ \\
\hline 4 & Assisten, Staf Ahli, Tim Kerja & 9 & $6,800,000.00$ \\
\hline 5 & PKK Kabupaten & 100 & $15,000,000.00$ \\
\hline 6 & TNI, POLRI, UMUM & 30 & $1,280,000.00$ \\
\hline 7 & Dinas Pelayanan Terpadu Satu Pintu & 42 & $4,200,000.00$ \\
\hline 8 & Bagian Ekonomi \& Pembangunan & 18 & $4,100,000.00$ \\
\hline 9 & Dinas Sosial & 36 & $4,600,000.00$ \\
\hline 10 & Dinas Kominpo & 36 & $4,500,000.00$ \\
\hline 11 & Bagian TUP & 34 & $5,180,000.00$ \\
\hline 12 & Badan Lingkungan Hidup & 44 & $4,850,000.00$ \\
\hline 13 & SATPOL PP & 34 & $4,300,000.00$ \\
\hline 14 & BKPD & 85 & $10,450,000.00$ \\
\hline 15 & Setwan Aleg & 61 & $7,100,000.00$ \\
\hline 16 & Dinas Pekerjaan Umum (PU) & 61 & $10,189,000.00$ \\
\hline 17 & Dinas Perum, Pemukiman \& Pertanahan & 33 & $4,400,000.00$ \\
\hline 18 & Pemberdayaan Masyarakat Dan Desa & 36 & $4,500,000.00$ \\
\hline 19 & Dinas Kelautan dan Perikanan & 21 & $3,800,000.00$ \\
\hline 20 & Bagian Kesra & 23 & $2,000,000.00$ \\
\hline 21 & BAPPEDA & 60 & $6,800,000.00$ \\
\hline 22 & Bagian ULP & 13 & $1,300,000.00$ \\
\hline 23 & Dinas Perpustakaan & 22 & $3,750,000.00$ \\
\hline 24 & Dinas Keluarga Berencana Dan PP & 68 & $8,284,000.00$ \\
\hline 25 & Dinas Kesehatan & 437 & $58,359,000.00$ \\
\hline 26 & Dinas Perindakop & 52 & $5,435,000.00$ \\
\hline 27 & Bagian Hukum & 57 & $2,360,000.00$ \\
\hline 28 & PDAM & $7,100,000.00$ \\
\hline & & & \\
\hline
\end{tabular}

${ }^{24}$ H. Imran Gaib, S.Sos.I, Kasubag Keagamaan Kesra Kabupaten Bone Bolang, Wawancara, di Bone Bolango, tanggal 25 Februari 2019. 
Faisal Pakaya, Lahaji

\begin{tabular}{|c|c|c|c|}
\hline 29 & INSPEKTORAT & 51 & $6,000,000.00$ \\
\hline 30 & Dinas Parawisata & 38 & $4,400,000.00$ \\
\hline 31 & Dinas Perhubungan & 34 & $4,570,000.00$ \\
\hline 32 & BKPPD & 68 & $7,800,000.00$ \\
\hline 33 & Bagian Humas & 28 & $2,100,000.00$ \\
\hline 34 & RS Toto & 390 & $23,017,000.00$ \\
\hline 35 & Dinas Pertanian dan Peternakan & 160 & $17,060,000.00$ \\
\hline 36 & Dinas Pendidikan & 1270 & $147,962,100.00$ \\
\hline 37 & Dinas Dukcapil & 37 & $4,750,000.00$ \\
\hline 38 & Dinas Kesbangpol & 23 & $2,900,000.00$ \\
\hline 39 & BPBD & 52 & $3,600,000.00$ \\
\hline 40 & RS Tombulilato & 57 & $6,720,000.00$ \\
\hline 41 & Dinas Pemuda dan Olah Raga & 19 & $3,213,300.00$ \\
\hline 42 & KPU & 21 & $2,100,000.00$ \\
\hline 43 & Dinas Pangan & 35 & $5,164,000.00$ \\
\hline 44 & Bagian Tapem & 20 & $2,400,000.00$ \\
\hline 45 & Bagian Umum & 46 & $6,958,000.00$ \\
\hline 46 & BNN & 10 & $2,500,000.00$ \\
\hline 47 & Komisioner BAZNAS & 4 & $2,000,000.00$ \\
\hline 48 & BPPD & 10 & $8,284,000.00$ \\
\hline 49 & Bank Sulutgo & 10 & $2,500,000.00$ \\
\hline 50 & Kecamatan Bone & 56 & $6,070,000.00$ \\
\hline 51 & Kecamatan Bone Raya & 39 & $4,132,000.00$ \\
\hline 52 & Kecamatan Bulawa & 105 & $10,300,000.00$ \\
\hline 53 & Kecamatan Bonepantai & 165 & $17,000,000.00$ \\
\hline 54 & Kecamatan Kabila Bone & 21 & $8,550,000.00$ \\
\hline 55 & Kecamatan Kabila & 81 & $7,563,000.00$ \\
\hline 56 & Kecamatan Botupingge & 16 & $3,710,000.00$ \\
\hline 57 & Kecamatan Tilongkabila & 84 & $7,165,000.00$ \\
\hline 58 & Kecamatan Suwawa & 176 & $17,150,000.00$ \\
\hline 59 & Kecamatan Suwawa Tengah & 20 & $3,500,000.00$ \\
\hline 60 & Kecamatan Suwawa Selatan & 102 & $10,215,000.00$ \\
\hline 61 & Kecamatan Suwawa Timur & 34 & $9,700,000.00$ \\
\hline 62 & Kecamatan Tapa & 32 & $5,010,000.00$ \\
\hline 63 & Kecamatan Bulango Utara & 142 & $13,550,000.00$ \\
\hline 64 & Kecamatan Bulango Timur & 27 & $4,825,000.00$ \\
\hline 65 & Kecamatan Bulango Selatan & 56 & $8,000,000.00$ \\
\hline 66 & Kecamatan Bulango Ulu & 32 & $3,200,000.00$ \\
\hline 67 & Kecamatan Pinogu & 10 & $1,024,000.00$ \\
\hline 68 & Kementerian Agama & 60 & $6,200,000.00$ \\
\hline 69 & Kantor Badan Pertanahan & 7 & $2,000,000.00$ \\
\hline \multirow[t]{2}{*}{70} & BPS & 27 & $1,000,000.00$ \\
\hline & Jumlah & 5104 & $637,999,400.00$ \\
\hline
\end{tabular}

Sumber: Data Baznas Kabupaten Bone Bolango Tahun 2018 
Implementasi Zakat Profesi terhadap Aparatur Sipil Negara di Pemerintah Daerah Kabupaten Bone Bolango

Tabel 3 di atas diketahui bahwa seluruh OPD yang menyalurkan zakat, infaq dan sedekahnya sejumlah 60 OPD di luar instansi vertikal, seperti Kementerian Agama, TNI/Polri, Badan Pusat Statistik (BPS), Badan Narkotika Nasional (BNN) dan Badan Pertanahan Nasional (BPN).

Ketua Baznas Kabupaten Bone Bolango berharap dengan adanya even tersbut akan meningkatkan pengumpulan zakat profesi ASN di Kabupaten Bone Bolango. Dalam beberapa kesempatan saya bertemu dengan beberapa rekan, mereka menyatakan memang ada berupa ketidakpercayaan terhadap lembaga Baznas, dan hal ini menjadi tantangan saya sebagai Ketua untuk memulihkan kembali kepercayaan tersebut. ${ }^{25}$

Setelah kegiatan gerakan zakat infaq sedekah tanggal 23 Januari 2018 memberikan dapat terhadap peningkatan pengumpulan zakat dan menambah kesadaran para ASN dalam mengeluarkan zakat infaq sedekah. Hal ini dapat dilihat pada tabel berikut ini:

Tabel 4

Jumlah Zakat, Infaq dan Sedekah Tahun 2018

\begin{tabular}{|r|l|r|}
\hline No & \multicolumn{1}{|c|}{ Uraian } & Jumlah Pemasukan \\
\hline 1 & Bagian Tapem & $300,000.00$ \\
\hline 2 & Bagian Hukum & $360,000.00$ \\
\hline 3 & Dinas PU & $5,819,000.00$ \\
\hline 4 & Dinas Pend. Tilongkabila & $7,080,000.00$ \\
\hline 5 & Diknas Suwawa Timur & $1,705,000.00$ \\
\hline 6 & Setoran Zakat Agustus-Desember 2017 & $30,959,000.00$ \\
\hline 7 & Setoran Zakat Kemenag & $6,041,000.00$ \\
\hline 8 & Setoran Infaq & $1,500,000.00$ \\
\hline 9 & Zakat Mal & $1,500,000.00$ \\
\hline 10 & Sairah Yusuf & $100,000.00$ \\
\hline 11 & KPU & $700,000.00$ \\
\hline 12 & KPU & $700,000.00$ \\
\hline 13 & Ronaldi Kasim & $1,000,000.00$ \\
\hline 14 & Setoran Dikbud September 2017 & $389,318.00$ \\
\hline 15 & Setoran BAZ Dikbud Oktober 2017 & $389,318.00$ \\
\hline 16 & Setoran BAZ dikbud Januari 2018 & $2,412,500.00$ \\
\hline 17 & Setoran BAZ Dikbud Februari & $2,487,500.00$ \\
\hline 18 & Setoran Dikbud Suwawa Tengah & $1,760,000.00$ \\
\hline 19 & Setoran Lili Dalu & $435,000.00$ \\
\hline 20 & Saira Yusuf & $100,000.00$ \\
\hline
\end{tabular}

${ }^{25}$ H. Harun S. Badjoda, S.IP., Ketua Baznas Kabupaten Bone Bolango, Wawancara, di Bone Bolango, tanggal 26 Februari 2019. 
Faisal Pakaya, Lahaji

\begin{tabular}{|c|c|c|}
\hline 21 & SKN-NG BSMDIDJA & $13,961,381.00$ \\
\hline 22 & Saira Yusuf & $100,000.00$ \\
\hline 23 & Hasna Abdan & $3,750,000.00$ \\
\hline 24 & PKM Pinogu & $2,100,000.00$ \\
\hline 25 & Husain Sahrain & $30,000.00$ \\
\hline 26 & Kantor camat Bulango Timur & $1,750,000.00$ \\
\hline 27 & Saira Yusuf & $100,000.00$ \\
\hline 28 & Saira Yusuf & $100,000.00$ \\
\hline 29 & RSUD Toto & $16,100,000.00$ \\
\hline 30 & Transferanonim & $1,422,000.00$ \\
\hline 31 & Saira Yusuf & $100,000.00$ \\
\hline 32 & Kantor camat Suwawa & $1,320,000.00$ \\
\hline 33 & DPPKB dan P3A & $4,515,000.00$ \\
\hline 34 & Kemenag Bone Bol & $20,000,000.00$ \\
\hline 35 & Kantor Camat Bulango Utara & $1,470,000.00$ \\
\hline 36 & Kacam Bulango Utara maret- juni 2018 & $3,080,000.00$ \\
\hline 37 & MAN Insan Cendekia & $1,250,000.00$ \\
\hline 38 & Diknas Bone Bolango Juni 2018 & $2,530,000.00$ \\
\hline 39 & Diknas April 2018 & $2,502,500.00$ \\
\hline 40 & Diknas Maret 2018 & $2,510,000.00$ \\
\hline 41 & Diknas Mei 2018 & $2,565,000.00$ \\
\hline 42 & Dinas Perpustakaan & $440,000.00$ \\
\hline 43 & Bayar Zakat ASN & $1,525,000.00$ \\
\hline 44 & Baznas Bone Bolango & $1,050,000.00$ \\
\hline 45 & Dinas Pangan & $740,000.00$ \\
\hline 46 & Dinas Perhubungan & $1,750,000.00$ \\
\hline 47 & Bappeda & $1,353,723.00$ \\
\hline 48 & Dinas Pangan & $680,000.00$ \\
\hline 49 & Bappeda & $1,401,918.00$ \\
\hline 50 & Transfer Anonim & $100,000.00$ \\
\hline 51 & Diknas Juli 2018 & $2,520,000.00$ \\
\hline 52 & Diknas Agustus & $2,512,000.00$ \\
\hline 53 & Diknas September & $2,462,500.00$ \\
\hline 54 & SMP Satap Bulango Utara & $728,000.00$ \\
\hline 55 & Setoran Anonim & $3,330,000.00$ \\
\hline 56 & Bappeda & $1,447,320.00$ \\
\hline 57 & Dinas Pangan & $710,000.00$ \\
\hline 58 & Dikbud Desember & $2,472,500.00$ \\
\hline 59 & Dikbud November & $2.472,500.00$ \\
\hline \multirow[t]{4}{*}{60} & Dikbud Oktober & $2,472,500.00$ \\
\hline & Jumlah & $163,200,107.00$ \\
\hline & Jumlah Pengumpulan Rekor Muri 23 Januari 2018 & $637,999,400.00$ \\
\hline & Total & $801,199,507.00$ \\
\hline
\end{tabular}

Sumber: Data Baznas Kabupaten Bone Bolango Tahun 2018 
Implementasi Zakat Profesi terhadap Aparatur Sipil Negara

di Pemerintah Daerah Kabupaten Bone Bolango

\section{Persepsi Aparatur Sipil Negara Kabupaten Bone Bolango tentang Zakat Profesi}

Manusia sebagai makhluk sosial yang sekaligus juga sebagai makhluk individual, maka terdapat perbedaan antara individu yang satu dengan yang lainnya. Adanya perbedaan inilah yang antara lain menyebabkan mengapa seseorang menyenangi suatu obyek, sedangkan orang lain tidak senang bahkan membenci obyek tersebut. Hal ini sangat tergantung bagaimana individu menanggapi obyek tersebut dengan persepsinya. Pada kenyataannya sebagian besar sikap, tingkah laku dan penyesuaian ditentukan oleh persepsinya. Persepsi meliputi pengetahuan, dengan demikian persepsi mencakup penafsiran objek-objek, simbol-simbol dan orang-orang, dipandang dari sudut pengalaman penting. ${ }^{26}$

Berbagai penjelasan terkait pengertian persepsi, antara lain menurut Deddy Mulyana bahwa persepsi adalah proses internal yang memungkinkan seseorang memilih, mengorganisasikan, dan menafsirkan rangsangan dari lingkungan kita, dan proses tersebut mempengaruhi perilaku seseorang. ${ }^{27}$ Sedangan dalam Wikipedia menjelaskan bahwa persepsi adalah sebuah proses saat individu mengatur dan menginterpretasikan kesan-kesan sensoris guna memberikan arti bagi lingkungan mereka. ${ }^{28}$

Menunaikan zakat merupakan kewajiban umat Islam yang mampu dan hasil pengumpulan zakat merupakan sumber dana yang potensial bagi upaya mewujudkan kesejahteraan masyarakat. Zakat sebagai kewajiban bagi umat Islam yang jika dijalankan dengan semestinya, akan memberi dampak sangat kongkret dalam proses pertumbuhan ekonomi masyarakat. Zakat, selain berfungsi sebagai sarana mendekatkan diri kepadaAllah, juga berfungsi sebagai sarana penciptaan kerukunan hidup antara golongan kayadan miskin. Selain itu, mengeluarkan zakat dapat mencegah monopoli harta kekayaan oleh orang-orang kaya. Selain sebagai kewajiban umat Islam, zakat merupakan pranatakeagamaan dalam upaya mewujudkan keadilan sosial bagi seluruh umat Islam. Oleh karena itu, apabila dikelola dengan baik dan benar, zakat dapat dijadikan sebagai salahsatu potensi ekonomi umat yang dapat dijadikan sumber dana yang dapat dimanfaatkan bagi kesejahteraan umat Islam, terutama untuk menanggulangi kemiskinan dan

\footnotetext{
${ }^{26}$ Winardi, Manajemen Perilaku Organisasi (Jakarta: Prenada Media, 2009), 204.

${ }^{27}$ Deddy Mulyana, Ilmu Komunikasi Suatu Pengantar (Bandung: Rosda Karya, 2005), 167.

${ }^{28}$ https://www.id.wikipedia.org/wiki/persepsi/ diakses tanggal 3 April 2019
} 
menghilangkan kesenjangan sosial. Untuk maksud ini perlu ada pengelolaan zakat secara profesional dan bertanggungjawab yang dilakukan bersama masyarakat dan pemerintah.

Pemerintah dalam konteks ini berkewajiban memberikan perlindungan, pembinaan dalam pelayanan kepada muzakki, mustahik dan pengelola zakat. Khususnya pengelolaan zakat di Kabupaten Bone Bolango masih memerlukan perhatian serius dari pemerintah agar menjadikan zakat sebagai potensi ekonomi umat Islam di Kabupaten Bone Bolango. Sebagaimana disampaikan Hamdan Ladiku bahwa:

Melalui gerakan insidentil seperti gerakan zakat, infaq, sedekah, "5 menit 500 ASN 500 juta" merupakan sosialisasi faktual yang bersifat implementatif. Ketika kesadaran mulai tumbuh dan efek zakat mulai terasa maka meningkat menjadi gerakan yang regulative yang sifatnya insidentil. Gerakan ini belum bisa efektif jika kesadaran belum ada. Sebenarnya secara kemampuan mereka mampu, dari segi keinginan mereka ada kemauan. Harus dilakukan secara berstruktur melalui Baznas. makna "khudz," tafsir implementatif dalam bentuk lembaga Baznas. ${ }^{29}$

Untuk membangun kesadaran dan pemahaman lebih utuh harus ada kerjasama yang memerlukan tiga kekuatan untuk bersinergi, yaitu pemerintah, ulama dan muzakki (kalangan zakat profesi- ASN), sekaligus untuk memperlihatkan bahwa baznas menuntaskan kemiskinan. Karena pemerintah mempunyai daya tekan kepada kepala dinas melalui perintah, ditambah lagi dengan ulama yang faham dan menyuarakan tentang kewajiban zakat.

Hasil sebaran angket terhadap sampel 300 orang responden yang terdapat di 19 Organisasi Perangkat Daerah (OPD) di Kabupaten Bone Bolango dari jumlah populasi sebanyak 3780 orang diperoleh data sebagai berikut:

1. Pengetahuan tentang Zakat

a. Pertanyaan terkait hukum zakat bagi yang mampu dan sudah memenuhi syarat hisab dan haul dijawab oleh 300 responden sebagai kewajiban yang harus ditunaikan.

\footnotetext{
${ }^{29}$ Dr. Hamdan Ladiku, M.H.I., Tokoh Agama Kabupaten Bone Bolango, Wawancara, di Bone Bone Bolango, tanggal 7 Januari 2019.
} 
Implementasi Zakat Profesi terhadap Aparatur Sipil Negara di Pemerintah Daerah Kabupaten Bone Bolango

b. Pertanyaan terkait persepsi tentang posisi kewajiban shalat dan zakat dijawab sama posisinya oleh 277 responden, dan 23 responden menjawab shalat lebih wajib dari zakat.

c. Pertanyaan terkait pelaksanan kewajiban zakat dilaksanakan dijawab sudah oleh 300 responden.

d. Pertanyaan terkait pelaksanaan zakat berdasarkan ketentuan syariat dijawab sudah sesuai oleh 289 responden, dan 11 responden menjawab kadang-kadang.

2. Persepsi tentang Pengelolaan Zakat

a. Pertanyaan tentang persepsi tentang penyaluran zakat dijawab 63 respoden bahwa langsung kepada yang berhak menerima (mustahik); 10 responden menjawab langsung ke Panti Asuhan; 60 responden menjawab kepada keluarga; 150 responden menjawab melalui Baznas; dan 17 orang menjawab melalui imam masjid.

b. Pertanyaan tentang apakah amanah, transparan dan professional pengelola Zakat pada Baznas Kabupaten Bone Bolango bahwa 214 responden menjawab ya; 58 responden menjawab belum; dan 28 responden menjawab tidak tahu.

c. Pertanyaan tentang optimalisasi pengelolaan zakat oleh Baznas Kabupaten Bone Bolango bahwa 247 responden menjawab ya; 43 responden menjawab belum; dan 10 responden menjawab tidak tahu.

d. Pertanyaan tentang sosialisasi dan informasi dari LAZ, Baznas, ulama (da'i) sudah memadai, maka 50 responden menjawab ya; 152 responden menjawab belum; 27 responden menjawab tidak; 23 responden menjawab kadang-kadang; dan 48 responden menjawab tidak tahu.

3. Peran Pemerintah

a. Pertanyaan tentang persepsi perlunya Perda dan Perbup yang mengatur pengelolaan zakat, maka 300 responden menjawab perlu adanya.

b. Pertanyaan tentang Pemerintah Daerah Bone Bolango selalu menghimbau ASN membayar zakat māl, maka 293 responden menjawab perlu; 3 responden menjawab kadang-kadang; dan 4 responden menjawab tidak tahu. 
c. Pertanyaan tentang perlu adanya instruksi yang tegas kepada ASN membayar zakat penghasilan/profesi, maka 300 responden menjawab perlu.

d. Pertanyaan tentang perlunya Gerakan Membayar Zakat Infaq Sedekah, seperti pada kegiatan Rekor MURI pada tanggal 23 Januari 2018, maka 295 responden menjawab ya; 3 orang menjawab kadang-kadang; dan 2 responden menjawab tidak tahu.

e. Pertanyaan tentang kapan perlu diadakan gerakan membayar zakat, seperti pada Kegiatan Rekor MURI tanggal 23 Januari 2018, maka 16 responden menjawab setiap bulan; 31 responden menjawab 3 bulan 1 kali; 15 responden menjawab 4 bulan 1 kali; 40 responden menjawab 6 bulan 1 kali; dan 198 responden menjawab 1 bulan 1 kali.

Berdasarkan data di atas disimpulkan bahwa ASN di Kabupaten Bone Bolango pada prinsipnya tidak berkeberatan dalam hal pengumpulan zakat profesi atas penghasilan mereka. Ini menandakan bahwa ketaatan dalam menjalankan salah satu ajaran agama Islam sangat tinggi.

\section{E. Faktor Penghambat Implementasi Zakat Profesi}

Secara umum zakat dapat dirumuskan sebagai bagian dari harta yang wajib diberikan oleh setiap muslim yang memenuhi syarat kepada orangorang tertentu dan dengan syarat-syarat tertentu. syarat-syarat itu adalah nisab (jumlah minimum harta kekayaan yang wajib dikeluarkan zakatnya), haul (jangka waktu yang ditentukan bila seseorang wajib mengeluarkan zakat) harta, dan kadarnya (ukuran besarnya zakat yang harus dikeluarkan). ${ }^{30}$

Kewajiban zakat dibuktikan dengan adanya ayat Alquran dan hadis Nabi saw. dengan adanya suatu kewajiban agama. Zakat merupakan media kesalehan individual yang berpotensi untuk kesalehan sosial. Dalam norma agama, zakat merupakan bentuk ketaatan ibadah individu kepada Tuhannya, yang dalam praktik atau pemanfaatannya senantiasa berkaitan dengan kehidupan sosial. Secara filsafati, zakat mempunyai beberapa arti penting sebagaimana dikemukakan oleh al-Kasani yang dikutip oleh Yusuf alQardhawi, Pertama, menunaikan zakat merupakan upaya untuk menolong

\footnotetext{
${ }^{30}$ Mohammad Daud Ali dan Habibah Daud, Lernbaga-Lembaga Islam di Indonesia
} (Cet. I; Jakarta: Raja Grafindo Persada, 1995), 241. 
Implementasi Zakat Profesi terhadap Aparatur Sipil Negara di Pemerintah Daerah Kabupaten Bone Bolango

kaum lemah, membantu orang yang membutuhkan pertolongan dan menopang mereka yang lemah agar mampu melaksanakan apa yang diwajibkan Allah swt. Pada aspek tauhid dan ibadah, menyiapkan sarana untuk melaksanakan kewajiban juga merupakan suatu kewajiban; Kedua, membayar zakat dapat membersihkan diri pelaku dari berbagai dosa an menghaluskan budi pekertinya, sehingga menjadi orang yang pemurah. Realita menunjukkan bahwa pada umummya manusia cenderung kikir. Dengan mengeluarkan zakat, jiwanya dilatih bersikap pemurah, senang melakukan amanah, serta senantiasa memenuhi hak setiap orang.

Sasaran zakat dapat dilihat dari firman Allah swt. sendiri yang telah menentukan siapa saja yang berhak mendapatkan zakat tersebut, Dia lelah membaginya kepada delapan bagian yang terdiri atas dua tipe manusia, yaitu: Pertama, mereka yang mendapatkan jatah dari zakat karena membutuhkannya, mereka mendapatkannya sesuai dengan keperluannya, banyak atau pun sedikit, seperti fakir miskin, untuk kemerdekaan hamba sahaya, dan ibnu sabil (orang yang dalam perjalanan); Kedua, mereka yang mendapatkan bagian karena pertimbangan jasa, seperti pengumpul zakat, muallaf, orang yang berhutang, dan mereka yang berjuang di jalan Allah swt. Bila seseorang tidak membutuhkan dan tidak ada pula manfaat pemberian zakat kepadanya, maka ia tidak berhak mendapatkan bagian zakat tersebut. $^{31}$

Secara umum, ada tiga hak yang terkandung dalam kewajiban zakat, yaitu hak fakir miskin, hak masyarakat, dan hak Allah. Dengan kata lain ada kewajiban dalam harta orang-orang mampu yang harus ditunaikan untuk memenuhi hak pihak lain. Hak fakir miskin merupakan hak yang essensial dalam zakat karena Allah swt, telah menegaskan bahwa dalam harta kekayaan dan pendapatan seseorang, ada hak-hak orang miskin (QS alMa'ārij/70: 24-25), baik yang meminta-minta maupun yang diam saja. Adanya hak masyarakat dalam zakat juga disebabkan karena harta kekayaan yang didapat seseorang sesungguhnya berasal dari masyarakat, terutama kekayaan yang diperoleh melalui perdagangan dan badan usaha masyarakat itu harus dikembalikan kepada masyarakat, terutama melalui saluran sabilillah (QS al-Żariyāt/51: 19), sedangkan hak Allah adalah mutlak karana segala kekayaan diperoleh seseorang dari Allah, yang diberikan kepada seseorang untuk dinikmati, dimanfaatkan, dan diurus sebaik-baiknya. Menyebutkan zakat sebagai hak Allah adalah mendudukkan zakat sebagai

\footnotetext{
${ }^{31}$ Mohammad Daud Ali dan Habibah Daud, Lembaga-Lembaga Islam, 242.
} 
ibadah khassah (ibadah khusus) yang harus dilaksanakan dengan ikhlas dalam rangka melaksanakan perintah Allah swt. ${ }^{32}$

Begitu pula halnya terkait aturan negara Indonesia dapat dilihat melalui Undang-Undang Nomor 23 Tahun 2011 tentang Pengelolaan Zakat menyebutkan bahwa pengelolaan zakat bertujuan: (1) meningkatkan efektivitas dan efisiensi pelayanan dalam pengelolaan zakat; dan (2) meningkatkan manfaat zakat untuk mewujudkan kesejahteraan masyarakat dan penanggulangan kemiskinan. Tujuan pertama pengelolaan zakat menjadi dasar dalam melakukan pengumpulan dan pendistribusian zakat. Sehingga strategi pencapaian target pengumpulan dan pendistribusian zakat secara nasional perlu dilakukan secara simultan, terintegrasi, efektifit dan efisien. Untuk itu ada 6 (enam) aspek yang perlu dilakukan agar mampu mewujudkan kebangkitan zakat nasional, yaitu:

Pertama, aspek legalitas; Aspek legalitas mencakup sudah terbitnya Surat Keputusan pembentukan lembaga dan Surat Keputusan unsur pimpinan Baznas Provinsi dan Baznas Kabupaten/Kota. Sedangkan untuk seluruh organisasi pengelola zakat mendapatkan izin dari pemerintah melalui Kementerian Agama.

Kedua, aspek akuntabilitas dan kesesuaian syariah; Untuk Baznas, Baznas Provinsi dan Baznas Kabupaten. aspek ini mencakup laporan dan pertanggungjawaban secara berkala, pengesahan RKAT setiap tahun, audit at as laporan keuangan oleh Kantor Akuntan Publik (KAP) dan audit syariah. Sedangkan untuk LAZ mencakup laporan dan pertanggungjawaban secara berkala, audit atas laporan keuangan oleh KAP dan audit syariah. Untuk memberikan jaminan agar pengelolaan zakat nasional dapat berjalan sesuai dengan syariah Islam dan peraturan perundang-undangan yang berlaku, maka diperlukan pembinaan dan pengawasan yang berkesinambungan baik terhadap keuangan, program dan kesesuaian terhadap syariah.

Ketiga, aspek IT dan sistem; Baznas Provinsi, Baznas Kabupaten menerapkan SiMBA dengan baik, dan LAZ terintegrasi baik dengan SiMBA. Sehingga laporan kepada Presiden dan pemangku kepentingan perzakatan nasional dapat disampaikan secara berkala dan tepat waktu. Kehadiran SiMBA dirancang untuk keperluan pembuatan laporan, penyimpanan data dan informasi yang dimiliki oleh Baznas sebagai lembaga yang diamanati menjadi koordinator pengelolaan zakat secara nasional.

\footnotetext{
${ }^{32}$ Mohammad Daud Ali dan Habibah Daud, Lembaga-Lembaga Islam, 246.
} 
Implementasi Zakat Profesi terhadap Aparatur Sipil Negara di Pemerintah Daerah Kabupaten Bone Bolango

Dengan berbasiskan web, SiMBA merupakan aplikasi yang tersentralisasi sehingga dapat digunakan oleh Baznas Provinsi, Baznas Kabupaten dan LAZ tanpa harus melewati proses instalasi yang rumit.

Keempat, aspek penyaluran; Berdasarkan Zakat Core Principle dimana untuk menilai kinerja penyaluran zakat dilihat dari rasio pendistribusian terhadap pengumpulan zakat. Semakin tinggi rasio penyaluran terhadap pengumpulan zakat, maka semakin efektif pengelolaan zakat. Disamping itu, dalam penyaluran zakat diutamakan untuk mengentaskan orang miskin dari batas garis kemiskinan berdasarkan data dan standar Badan Pusat Statistik (BPS).

Kelima, aspek pengumpulan; Dalam rangka mengoptimalkan pengumpulan zakat secara nasional, maka Baznas, Baznas Provinsi, Baznas Kabupaten dan LAZ perlu melakukan edukasi terhadap muzaki dalam bentuk Kampanye zakat nasional yang dilakukan berkelanjutan. Hal ini penting agar muzakki memahami bahwa zakat adalah ibadah yang memiliki posisi yang sangat strategis, baik dari aspek keagamaan, sosial, ekonomi maupun kesejahteraan masyarakat. Untuk itu, Baznas mesti mampu memberikan kenyamanan dan jaminan bahwa zakat yang telah ditunaikan melalui Baznas itu sampai kepada mustahik. Kenyamanan ini diharapakan akan melahirkan kepercayaan yang berkelanjutan dari muzakki kepada Baznas.

Keenam, aspek pengembangan amil; Untuk meningkatkan dan menstandarkan kapasitas dan kompetensi amil secara nasional, maka perlu dilakukan pelatihan dan pembinaan yang sesuai dan mengacu pada standar nasional.

Dari keenam aspek di atas hanya aspek pertama yang sudah sepenuhnya dimiliki oleh Baznas Kabupaten Bone Bolango yaitu aspek legalitas. Baznas Bone Bolango sudah memiliki Perda, Perbup, SK Pengurus oleh yang ditandatangi oleh Bupati atas rekomendasi Baznas Pusat dan surat resmi lainnya. Sedangkan kelima aspek lainnya yang menjadi tolok ukur kepercayaan ASN dan masyarakat untuk meyalurkan zakat di Baznas masih dibenahi, hal ini merupakan kendala dan tantangan bagi Baznas Kabupaten Bone Bolango.

Aspek kesadaran masyarakat dan ASN juga yang menjadi hambatan dalam pengumpulan zakat. Kesadaran bahwa zakat merupakan perintah Allah sebagaimana perintah sholat belum sepenuhnya terpatri dalam diri 
masyarakat. Mereka masih berpemikiran bahwa zakat hanya setahun sekali, yaitu zakat fitrah.

Faktor lain yang menjadi penghambat Baznas Kabupaten Bone Bolango dalam mengimplementasikan zakat profesi adalah, keterbatasan fasilitas yang ada. Fasilitas fisik, pelayanan, peralatan operasional maupun financial. Saat ini bahkan sejak dibentuk Baznas Kabupaten Bone Bolango belum memiliki gedung sendiri yang representatif. Saat ini masih menempati ruangan yang berukuran $4 \times 7$ meter. Kendala lain adalah masalah dana yang berdampak pada kegiatan kampanye, sosialisasi, infornasi dan edukasi zakat. Di samping itu Petugas Baznas dalam proses pengumpulan belum sepenuhnya melakukan system "jemput bola," sehingga dalam pengumpulan zakat tidak tercapai secara maksimal. Penyebab lain yang turut andil atas kurang berhasilnya pengumpulan zakat adalah, tidak adanya Unit Pengumpul Zakat (UPZ) maupun koordinator di setiap OPD. Pemimpin yang baik seharusnya tidak boleh melupakan bawahan di sekitarnya, karena terdapat potensi yang dapat dimanfaatkan, termasuk potensi pahala yang bisa diraih bersama.

\section{F. Penutup}

Undang-Undang Nomor 23 Tahun 2011 dan Peraturan Pemerintah Nomor 14 Tahun 2014 mengamanatkan sejumlah aturan, di antaranya pemangku kepentingan zakat nasional meliputi: Pemerintah (Kementerian Agama), DPR, Pemerintah Provinsi, DPRD Provinsi, Pemerintah Kabupaten/Kota, DPRD Kabupaten/Kota, Baznas, Baznas Provinsi, Baznas Kabupaten/Kota, dan LAZ. Oleh sebab itu seharusnya tidak ada lagi keraguan bagi bupati maupun stakeholder untuk mengeluarkan instruksi yang tegas tentang pengumpulan zakat.

Pemahaman ASN tentang kewajiban zakat profesi masih beragam. Pemahaman ini berdampak pada tingkat kesadaran dan kepatuhan dalam membayar zakat, dalam hal ini Baznas, Pemerintah Daerah dan ulama hendaknya bersinergi dalam mensyiarkan zakat. Potensi zakat profesi bagi ASN di Kabupaten Bone Bone Bolango adalah sebesar Rp. 367,242,588.00 perbulan, atau mencapai 4 Milyard pertahun, apabila potensi ini dapat digali dan dikelola secara optimal, maka akan menjadi sumber dana untuk pembangunan masyarakat Kabupaten Bone Bolango, baik dari segi ekonomi, kesehatan, kesejateraan, maupun sumber daya manusia. 
Implementasi Zakat Profesi terhadap Aparatur Sipil Negara di Pemerintah Daerah Kabupaten Bone Bolango

\section{Daftar Pustaka}

Ali Mohammad Daud, dan Habibah Daud, Lembaga-Lembaga Islam di Indonesia. Cet. I; Jakarta: Raja Grafindo Persada, 1995.

Asnaini. Zakat Produktif dalam Perspektif Hukum Islam. Cet. I; Yogyakarta: Pustaka Pelajar, 2008.

El-Bantanie, Syafi'ie. Zakat Infaq dan Sedeqah. Bandung: Salamadani Pustaka Semesta, 2009.

Karim, Andiwarman A. Bank Islam Analisis Fiqh dan Keuangan. Jakarta: Raja Grafindo Persada, 2006.

Kementerian Agama RI. Al-Qur'an dan Terjemahnya. Jakarta: PT. Sinergi Pustaka Indonesia, 2012.

Khallaf, Abdul Wahhab. Ilm Usul Fiqh, terj. Moh. Zuhri, Ilmu Ushul Fiqh. Semarang: Toha Putra Group, 1994.

Muhammad. Zakat Profesi: Wacana Pemikiran dalam Fiqih Kontemporer. Jakarta: Salemba Diniyah, 2002.

Mulyana, Deddy. Ilmu Komunikasi Suatu Pengantar (Bandung: Rosda Karya, 2005.

Al-Qardhawi, Yusuf. Kiat Islam Mengentaskan Kemiskinan. Jakarta: Gema Insani Press, 1995.

Sabiq, Sayyid. Fiqh Sunnah. Jilid 1. Jakarta: Pena Publishing, 2002.

Sahhatih, Syauqi Ismail. Al-Bunuk al-Islâmiyah. Saudi Arabia: Dâr alSyurứq, $1397 \mathrm{H}$.

Al-Shawi Shalah, dan Abdullah al-Mushlih. Fiqh Ekonomi Keuangan Islam. Jakarta: Dârul Haq, 2008.

Winardi. Manajemen Perilaku Organisasi. Jakarta: Prenada Media, 2009.

https://www.id.wikipedia.org/wiki/persepsi/ 